\title{
Morphometric Analysis of Local Fish from Banyu Biru Lake, Pasuruan Compared with Closely Related to Tor spp. from Indonesia
}

\author{
Dwi Anggorowati Rahayu ${ }^{*}$, Endik Deni Nugroho', \\ Rodliyati Azrianingzih ${ }^{3}$, Nia Kurniawan ${ }^{3}$, Haryono ${ }^{4}$ \\ ${ }^{1}$ Biology Departement, Brawijaya University, Malang, Indonesia \\ ${ }^{2}$ Biology Department, State University of Malang, Malang, Indonesia \\ ${ }^{3}$ Biology Departement, Brawijaya University, Indonesia \\ ${ }^{4}$ Zoological Dvision, Reesearch Center for Biology, Indonesian Institute of Sciences, Bogor Indonesia
}

\begin{abstract}
Banyu Biru is a natural lake in Sumber Rejo Village, Winongan District, Pasuruan Regency. There are local fishes in the Banyu Biru called sengkaring and tambra. Biological studies on these fishes are not so much known. This study aims to identify the relationship of sengkaring and tambra compared with the related species (Tor spp.: Cyprinidae) from Indonesia. Morphometric analysis can be used to clustering and understanding the relationship of taxa. Each species represents 17 specimens (Tambra and Sengkaring) and measured 22 characters (in $\mathrm{mm}$ ) by using digital caliper and the additional characters (21 characters). The canonical, clustering, similarity and distances were used. Based on morphometric measurements, sengkaring and tambra had similarity with the four species found in Indonesia. Currently, we are analyzing the deep relationship and identify the taxonomic of the two specimens using DNA Barcode COI and $16 S r R N A$ gene. Commonly, the population of Sengkaring and Tambra was critical; therefore, studies needed to be carried out to support conservation.
\end{abstract}

Keywords: Morphometric analysis, Local fish (Sengkaring and Tambra), similarity, conservation

\section{INTRODUCTION}

Banyu Biru Lake is a natural lake located in Sumberejo Village, Winongan District, Pasuruan Regency. There is a local fish in the Banyu Biru called sengkaring, a sacred fish which is found only in this lake. According to the public, the numbers of sengkaring fish remain constant throughout the year. They also state that illegal capture of this fish would lead to plague. This local belief determines the foundation of conservation strategies for sengkaring fish [1].

Beside Sengkaring fish, in Banyu Biru Lake there is Tambra fish. In terms of cursory of morp hology, Sengkaring and Tambra are a bit difference, but it is important to conduct compre

\footnotetext{
${ }^{*}$ Corresponding author:

Dwi Anggorowati Rahayu

Biology Department, Faculty of Math and Natural Sciences,

Brawijaya University, Malang, Indonesia

Email: doewira_89@yahoo.com
}

hensive analysis on these fishes. Comprehensive knowledge on these fishes will add information on biodiversity database of fishes in Indonesia, thus open up new possibilities to manage these fishes. In these recent days, the population of tambra fish in the world is critical, so conservation is needed.

Tambra fish or Mahseer is also known as Kings of the rivers, and is included into Tor genus and Cyprinidae family. Indonesia has four species of Tor, there are: Tor tambroides Blkr, T. tambra (C.V.), T. douronensis (C.V.) and T. Soro (C.V) [2]. There are about 20 different species which have been acknowledged as species under the Tor genus from all across Asia [3]. [4] Named its genera Labeobarbus, and differentiate species based on median fleshy lobe on their lower lip. The systematic classifictaion of Tor is still chaotic [5].

The taxonomy of Tor genus can be seen by fleshy lips, continuous angles at mouth; lower lip with or without a median lobe and uninterrupted 
post labial groove; and dorsal fin with a scaly sheath at its base [5]. Other recognize Tor by the following characters: lower lip developed into fleshy lobe or at least with two notches delimiting the usual position of the lobe; uninterrupted post labial groove; no horny sheath on the lower jaw; and a few (7-17) gill rakes on the lower arm [6]. Nowadays more and more Ichthyologists $[7,8]$ tend to treat all the previous subgenera as separate genera. Besides that, Tor genus also post the following characters: lower lip developed into fleshy lobe, or at least with two notches delimiting the usual position of the lobe; uninterrupted post labial groove; last simple dorsal fin ray osseous and non-serrated; no forward directed pre dorsal procumbent spine; no groove in front of nostrils [9].

The general description of Tor is that their bodies elongate and is moderately compressed. Its snout is more or less prominent; inferior or sub inferior mouth, horseshoe shaped; strongly protractile upper jaw. Its lips are more or less thick, continuous, the lower has uninterrupted transverse fold, the median part of which may be developed into a lobe. Four barbells: an anterior rostral pair, the other pairs behind corner of mouth. Sub orbital bone narrow. Dorsal with 8-9 bones branched rays and scaly sheath at its base; its origin somewhat before or opposite to origin of ventral; last osseous dorsalray enlarged and smooth. Anal with 5 branched rays. Large scale with fine, longitudinal or converging, more or less undulated lines [3].

Tor genus comes from Indonesia. The presence of sengkaring fish in Banyu Biru Lake has not been reported; there has been no effort even from the government, the Fisheries Department to study the existence of this fish. Studies are important related to the presence conservation and cultivation of the fish. The initial breakthrough research was conducted to describe the morphometric characteristic of the fish compared with Tor genus in Indonesia. This study can be seen as an effort to conserve this fish.

\section{MATERIALS AND METHODS}

Observation toward Sengkaring and Tambra was done in Banyu Biru Lake (Fig.1). The observation was conducted during May until
November 2012. Morphological observations were done on 17 samples of male and female from each type we found. Twenty-two measurements (in $\mathrm{mm}$ ) of body characters were taken using digital caliper. These characters are TL: total length, HL: head length, HW: head width, HD: head depth, ED: eye diameter, SNL: snout length, IW: interorbital width, ML: mouth length, BD: body depth, BW: body width, CPL: caudal peduncle length, CPD: caudal peduncle depth, DBL: dorsal fin base length, DFH: dorsal fin height, PL: pectoral fin length, VBL: ventral fin base length, ABL: anal fin base length, PPL: pre pelvic length, PAL: pre anal length, PDL: pre dorsal length, SNBL: snout barbell length, MXBL: maxillary barbell length [10].

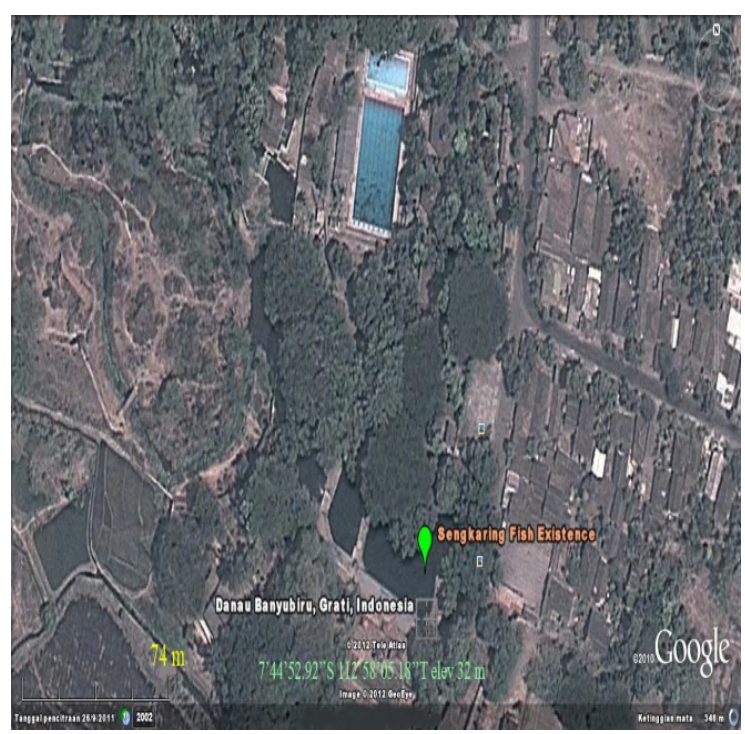

Figure 1. The location of Banyu Biru Lake, Sumberrejo Village, Pasuruan Residence.

Each species was represented by the 17 samples of male and female from each type we found and measured 22 characters (in $\mathrm{mm}$ ). To standardize the different body sizes among the samples, each measurement was divided by the SL (standart lenght) and converted to percentage. The converted data was transformed into $\log 10$ value before being subjected to principal component analysis and clustering analysis based on Euclidean distances using PAST software. We determine the characteristic of this fish with Tor genus in Indonesia [4]. There are Tor tambroides. Blkr, T. tambra (C.V.), T. douronensis (C.V.) and T. soro (C.V). 


\section{RESULTS AND DISCUSSION}

The sample size, mean, and standard deviation from this table we know that sengkaring has larger average head length, head depth, mouth length, and pre pelvic length than the other species. This result is important to compare among species of tambra fish, and among species of Tor separated based on median lobe on lower lip. Tambra and sengkaring has thick, continuous lips, the lower one with median, more or less developed square lobe, the hindborder of which does not reach the line connecting the corners of the mouth (figure 2).

Tambra and Sengkaring have large of head and mouth. The head is elongated allowing it to easily swim headlong against fast flowing waters with minimal resistance. This fish has four barbels: an anterior rostral pair, the other pair behind the corner of the mouth. The snout is obtusely rounded. The mouth is slightly inferior, making it well adapted for feeding off the sub-stratum of fast flowing streams and rivers. Generally, mature females have a more rounded belly as compared to males, which usually have a firmer and more keeled ventral surface. The large scales are descriptive of this group of fishes.
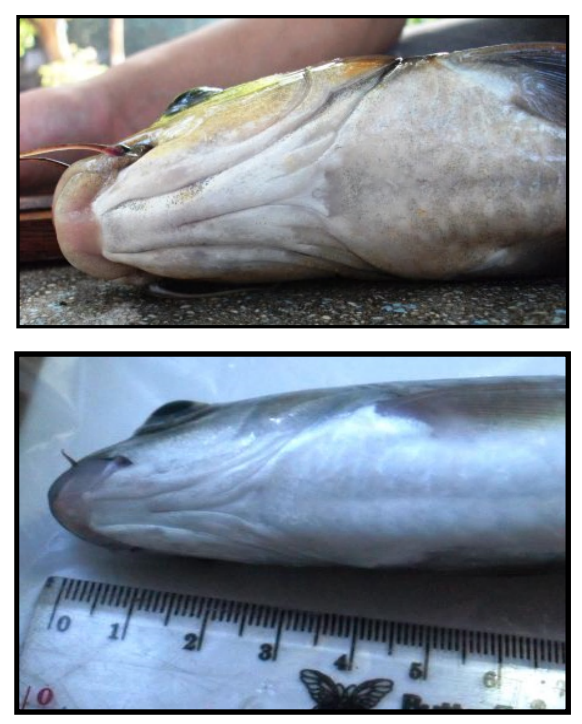

Figure 2. The median lobe at lower lips A. Tambra B. Sengkaring. White arrow points the median lobe.

Cladogram based on morphometric measurements showed that Tambra belongs to one clade with Tor tambra, but in different clade with Tor tambraides, Tor duoronensis, and Tor soro. This clustering is based on the similarity and disimilarity of transformed data derived from 22 characters measurements (Table 1). Tambra has $99.97 \%$ similarity with sengkaring, and had similarity with the other four species found in Indonesia.

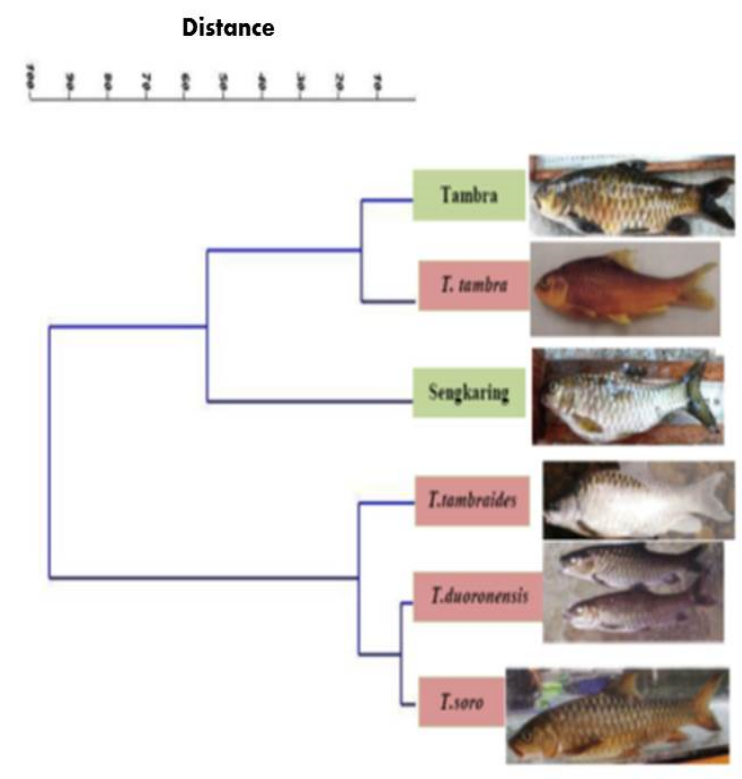

Figure 3. Dendogram based on morphometric characters in Banyu Biru Lake

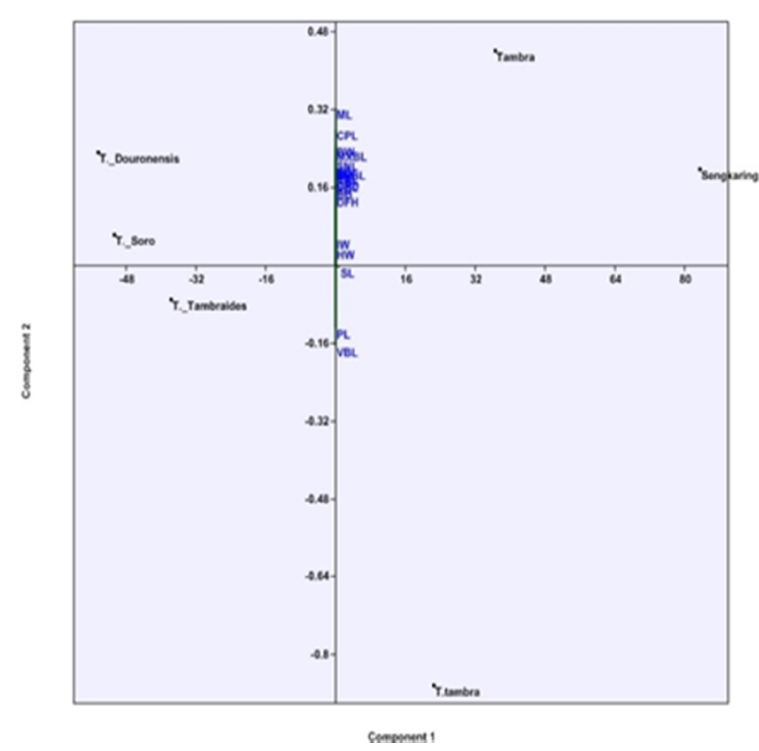

Figure 4. Plot of principal component 1 (PC1) versus principal component 2 (PC2) for the principal component analysis of sengkaring and tambra compared with other Tor genus in Indonesia. 
Currently, we are analyzing the deep relationship and identify the taxonomy of two specimens using DNA Barcode COI and 165 $r R N A$ gene. In these recent days, the populationof tambra fish in the world is critical, so conservation is needed.

\section{CONCLUSIONS}

Based on morphometric measurements, it is known that Tambra belongs to one clade with Tor tambra, but in different clade with Tor tambraides, Tor duoronensis, and Tor soro. Tambra has $99.97 \%$ similarity with sengkaring, and had similarity with the other four species found in Indonesia. All species of Tor are potential, yet their population is critical thus conservation is needed.

\section{REFERENCES}

1. Rahayu DA, Nugroho ED, Azrianingzih R (2012) Community Perceptions around Banyu Biru Lake on Sengkaring Fish Existence and Its Implications in Conservation Strategy. Procee ding on International Conference on Global Resource Conservation, Brawijaya UniversityMalang. Indonesia

2. Maurice K, Whitten AJ, Kartikasari SN, Wirjoatmodjo S (1993) Ikan Air Tawar Indonesia Bagian Barat dan Sulawesi. Jakarta: Periplus Edition.

3. Kiat Ng-Chi (2004) The Kings of the Rivers Mahseer in Malaysia and the Region. Selangor: Inter Sea Fishery.

4. Haryono and Tjakrawidjaja AH (2006) Morphological Study for Identification Improvement of Tambra Fish (Tor spp.: Cyprinidae) from Indonesia. Biodiversitas. 7: 5962.

5. Weber M, Beaufort LF (1916) The fishes of the Indo-Australian archipelago III, Ostariophysi: II. Cyprinoidea, Apodes, Synbranchi. EJ Brill Ltd. Leide.

6. Kottelat M, Whitten AJ, Kartikasari SN, Wirjoatmodjo S (1993) Freshwater Fishes of Western Indonesia and Sulawesi. Singapore: Periplus.

7. Weber M and Beaufort LF (1916) The fishes of the Indo Australian archipelago III, Ostariophysi: II. Cyprinoidea, Apodes, Synbranchi. Leiden: EJ Brill Ltd.

8. Kottelat M (2001) Fishes of Laos. Colombo. Srilangka: WHT. Publications. (Pte) Ltd.
9. Chen Z and Yang J (2004) A new species of genus Tor from Yunan China (Teleostei: Cyprinidae). Environ. Biol Fishes. 70: 185-191.

10. Hubbs, C.L. and K.F. Lagler. 1974. Fishes of The Great Lakes Region. Ann Arbor, MC.: University of Michigan Press. 